\title{
NATALIA ANANIEWA
}

Moskiewski Uniwersytet Państwowy im. M. Łomonosowa Moskwa, Rosja

\section{O chlebie powszednim. Nazwy chleba i wyrobów piekarniczych w języku polskim i rosyjskim}

Chleb (tak samo jak woda) należy do substancji, bez których niemożliwe jest istnienie człowieka jako istoty biologicznej. To, że chleb i woda mają pierwszorzędne znaczenie w jego życiu, potwierdzają zarówno rosyjskie, jak i polskie przysłowia: Хлеб всему голова; Хлеб и соль на столе, а руки свое; Хлебом не корми (сzуli podstawowym produktem), дай посмотреть (сделать itp.) что-либо; Chleb $i$ woda - nie ma głoda; Chleb z woda życie utwierdzaja; Przy chlebie $i$ wodzie nie wspomni się o głodzie; Chleb $i$ woda ludzka wygoda; Kiedy jest chleb przy wodzie, tam głód nie dobodzie; Chleb, sól i woda — kozacka wygoda (część polskich przysłów przytaczam z pracy Włodzimierza Wysoczańskiego z 2013 roku ${ }^{1}$ ).

O „chleb powszedni” (хлеб насущзный) prosi człowiek Boga w codziennej modlitwie Ojcze nasz; plebs w Rzymie żądał od władzy „chleba i igrzysk”; chleb jako wynik pracy występuje w przysłowiu Bez pracy nie ma kołaczy i nawet biblijne Nie samym chlebem żyje człowiek (Не хлебом единым живет человек) zakłada dołączenie czegoś duchowego do pierwszorzędnej potrzeby człowieka. Wyraz „chleb” jako nazwa podstawowego produktu spożycia może występować w funkcji uogólnionej nominacji jedzenia, a czasem mienia i dobrobytu człowieka: хлебное место (por. łacińskie habet haec res panem — это доходное мecmo); chlebodawca = pracodawca; chlebak jako worek do przenoszenia żywności; lekki chleb (легкий хлеб); odbierać koтиś chleb (отбирать хлеб у кого-

${ }^{1} \mathrm{~W}$. Wysoczański, Zespalanie pojęć z wyrazem woda we frazeologii oraz w paremiologii polskiej i stowackiej, [w:] „Вода” в славянской фразеологии и паремиологии. A víza szláv frazeológiában és paremiológiában. Water in Slavonic Phraseology and Paremiology, red. Z. András, O. Fedosov, J. Szabolcs, t. 1, Budapest 2013, s. 222. 
то); za chlebem — w poszukiwaniu chleba, czyli zarobku, не зря есть свой хлеб; лишиться куска хлеба; работать ради (из-за) куска хлеба; przysłowie $\mathrm{Ha}$ чужсой каравай (czyli własność) рот не разевай, а свой припасай i inne.

Nazwa wyrobu piekarniczego może pełnić funkcję czegoś atrakcyjnego (por. ни за какие коврижки не заманишь). Porównaj indywidualne autorskie крендель w tym znaczeniu u Aleksandry Maryniny: Идет себе, мечтает о кренделях небесных ${ }^{2}$.

Porzekadło zawierające nazwę wyrobu piekarniczego może mieć znaczenie przykrej niespodzianki: Masz, babo, placek!

Honorowego gościa częstuje się chlebem (караваем, kołaczem) i solą, a gościnnego gospodarza Rosjanie nazywają хлебосольнымм. Porównaj także pierwszą część (życzeniową) w powiedzeniu: Хлеб да соль! — Ем, да свой, А ты рядом постой.

Mimo że chleb stanowi podstawę jedzenia, postrzegany jest jednocześnie jako substancja niewystarczająca do normalnego funkcjonowania (życia) człowieka. O ubóstwie jedzenia składającego się z samego chleba (i wody) świadczą frazeologizmy: посадить кого-либо на хлеб и воду; перебиваться с воды на хлеб (или с хлеба на воду); skazać kogoś na chleb i wodę; żyć o chlebie i wodzie. Porównaj użycie w poemacie Xopomo! (Dobrze!) Włodzimierza Majakowskiego: Императора?/ На воду?/ И иерную корку? ${ }^{3}$ O skąpym charakterze spożycia samego chleba i wody świadczy również przysłowie Щи да кама пища наша. Хлеб да вода - солдатская еда.

Nominacje chleba i wyrobów piekarniczych zajmują ważne miejsce w języku, a same desygnaty odgrywają znaczącą rolę w obrzędach słowiańskich. Nazwy chleba i produktów z ciasta i mąki pełnią nie tylko funkcję denotatywną, lecz także konotatywną. Na przykład i Polacy, i Rosjanie często używają w znaczeniu przenośnym takich nazw, charakteryzując człowieka: pol. stary piernik (pejoratywnie o starym człowieku); ros. cyxaps (o chudej i wysokiej albo nieczułej, oschłej osobie) (zob. cały łańcuch porównań zawierających nazwy wyrobów z ciasta w wierszu Wandy Chotomskiej Sześć kucharek: Byto sobie sześć kucharek: / Jedna chuda jak sucharek, / Jak buteczka pulchna druga, / trzecia jak makaron dluga [...] / Piąta niby paczek thusta ${ }^{4}$ ); ros. тертый калач (о doświadczonym człowieku), któremu odpowiada polskie przysłowie Nie z jednego pieca chleb jadat; ros. пьши(еч)ка, пампуш(еч)ка, пончик (о grubej, korpulentnej osobie); ros. gwar. ша́ньга obelżywie 'twarz' (ща́ньга - 'ватрушка с творогом, ягодами, картофелем и $\partial p^{5}$ ).

\footnotetext{
2 А. Маринина, Последний рассвет, Москва 2014, s. 476.

3 В. Маяковский, Стихотворения и поэмы в двух томах, t. 2. Поэмы, Москва 1961, s. 186.

4 B. Bartnicka et al., Mь учим польскй язык. Начальный курс. 1. Тексты, Warszawa 1999,
} s. 61 .

5 Л.Е. Элиасов, Словарь русских говоров Забайкалья, Москва 1980, s. 460. 
Warto przytoczyć jeszcze przykład indywidualnego przenośnego użycia nazwy wyrobu piekarniczego z literatury pięknej: После субботьл я этого кренделя (,faceta”) в глаза не видел 6 .

Wyrazy „chleb” i ,mąka” występują także w polskim przysłowiu oznaczającym nieprzydatnego człowieka: Z tej mąki chleba nie będzie (Из него не будет толка). Idiom przeciętny zjadacz chleba oznacza natomiast przeciętnego, zwykłego człowieka. Z nazwami wyrobów piekarniczych porównuje się działania człowieka (por. idiomy свернуться калачиком [zwinąć się w kłębek]; leżeć plackiem; paść plackiem; żyć na łaskawym chlebie [жить на чужих хлебах]; жить на казенных хлебах; получить дырку от бублика). Przenośnie nazwy chleba i wyrobów z ciasta i mąki mogą być używane dla oznaczania przedmiotów i zjawisk. Przykładowo: ros. второй хлеб (о ziemniakach), пирожок (nazwa czapki, zwykle z karakułów), баранка (kierownica) (por. крутить баранку; „Крепче за баранку держись, шофер" - zwrot z popularnej piosenki); и то хлеб (mówi się o czymś małym, z czego jednak można wyciągnąć pewne korzyści); pol. przekładaniec (w znaczeniu 'najrozmaitsze rzeczy', 'różności').

Pisarze i poeci używają różnych porównań i przenośni zawierających nazwy chleba i wyrobów piekarniczych. Na przykład W. Majakowski porównuje ziemię z chlebem: Земля — / подстилка под ихними ногами, / и вдруг / ее, / как хлебища в узел, / со всеми ружьями ее / и пригорками / крестьянин взял / и зажал, закорузел (poemat Владимир Ильич Ленин ${ }^{7}$ ). Borys Pasternak w wierszu Венеция porównuje to miasto z wyrobem piekarniczym: Размокшей каменной баранкой в воде Венеция пльла ${ }^{8}$. Nominacja баранка wchodzi też w skład idiomu utworzonego na zasadzie fonetycznej: Hy, баранки гну.

Nazwa wyrobu piekarniczego może również nabrać znaczenia symbolicznego. Na przykład w rosyjskim dyskursie politycznym zwrot раздавать печеньки występuje jako symbol przekupienia opozycji i jest używany ironicznie właśnie przez zwolenników ruchu opozycyjnego.

Nazwy wyrobów piekarniczych leżą ponadto u podstaw wielu nazwisk. Przykłady z języka rosyjskiego: Пирожков, Оладьин, Ковригин, Ситников, Калачев, Караваев, Хлебников, Тестов, Блинов, Блинников, Баранкин, Шаньгин. Wiele z tych antroponimów występowało już w XV wieku. Według Mikołaja Tupikowa przezwisko Оладья poświadczone jest w 1470 roku (Оладья Андреев). Zapis Оладья Блинов odnosi się z kolei do roku 1498. Nazwisko Оладьин znane jest od roku $1534^{9}$.

Chleb, jak już zasygnalizowałam, odgrywa ważną rolę w obrzędowości i kulturze sakralnej. Wchodzi on w skład 80 konceptów lingwokulturowych w jednoto-

${ }^{6}$ А. Маринина, op. cit., s. 400.

7 В. Маяковский, op. cit., s. 133.

8 Б. Пастернак, Сочиненияв 2-х томах, Тула 1993.

9 Za: П.Я. Черных, Историко-этимологический словарь современного русского языка, t. 1 А. Пантомима, Москва 1994, s. 596. 
mowym Słowniku ideograficznym języka rosyjskiego. Na przykład караваŭ (pol. kołacz) wypieka się na wesele, zajmuje on określone miejsce w obrzędzie pogrzebowym; butkę natomiast wrzuca się do rzeki w celu odnalezienia topielca. Wiele z tych obrzędów ma charakter ogólnoeuropejski. Porównaj małopolski tekst w $Z a$ rysie dialektologii polskiej Stanisława Urbańczyka, opowiadający o chłopcu, który pasł gęsi nad rzeką i utopił się, z opowiadaniem w Przygodach Hucka Marka Twaina o tej samej czynności (wrzucanie chleba do wody) w celu poszukiwania rzekomych topielców Tomka i Hucka (mamy zatem do czynienia ze zbieżnością obyczajów u Polaków i Anglosasów).

Istotną rolę w rosyjskiej kulturze ludowej odgrywają bliny (rodzaj naleśników), które przygotowuje się podczas stypy i w czasie zapustów. Rosyjska облатка (albo nросфора), tak samo jak polska hostia (a wcześniej opłatek), jest namiastką ciała Chrystusa podczas eucharystii. Polacy na Wielkanoc wypiekają babki, mazurki i sękacze, natomiast Rosjanie pieką куличи (na Kresach południowo-wschodnich w wyniku wpływu języka ukraińskiego odpowiednikiem ros. кулич jest paska). W Wigilię Polacy tamia się opłatkiem. W niektórych regionach Rosji, w tym nad Bajkałem, specjalnie dla koni 15 listopada według starego kalendarza (tzw. Гурьев день) wypieka się bocheneczek, który nazywa się пегашка (od nazwy maści koni: пегий — 'dereszowaty'). Rosyjskie жаворонки (skowronki) — pieczywo w kształcie ptaków - wypiekano w dzień Zwiastowania Najświętszej Maryi Panny. Na wesele Polacy piekli także szczodraki (,,placuszek, ciasto weselne w formie rozmaitych zwierząt" ${ }^{\prime 0}$ ). W staropolszczyźnie szczodrakiem nazywano „chleb, rogal dawany w podarunku w szczodry dzień, czyli „dzień, w którym obdarowywano domowników, znajomych i przychodzących z kolędą: w wilię Bożego Narodzenia, w wilię Nowego Roku lub wilię Trzech króli"11.

Z powyższego wynika, że tak samo jak chleb i wyroby z ciasta i mąki odgrywają ważną rolę w codziennym życiu człowieka, wyrazy oznaczające te desygnaty zajmują istotne miejsce w języku. Kontrastywne badanie tego słownictwa w języku polskim i rosyjskim przyjmuje możliwość wieloaspektowego podejścia do danego tematu. Wymienię niektóre $\mathrm{z}$ tych aspektów.

1. Analiza leksykalno-semantyczna zakładająca wyodrębnienie w ramach pola tematycznego (semantycznego) ,,chleb i wyroby piekarnicze” subpól i mikropól, których składniki porównujemy w obydwu językach. Zestawiać możemy właściwości formalne i semantyczne składników, wykrywać miejsce (centralne bądź peryferyjne), które zajmują formalnie identyczne nominacje w systemach pokrewnych języków. Przykładowo: różny zakres znaczeń mają ros. хлеб i pol. chleb. Rosyjski хлеб charakteryzuje szerszy zakres znaczeń, ponieważ oznacza nie tylko upieczony wyrób, lecz także zboże (хлеба зеленеют). Oprócz tego w znaczeniu „wyrób pieczony” w pol-

${ }^{10}$ M. Arct, Stownik ilustrowany języka polskiego, t. 2, wyd. 3, Warszawa 1929, s. 873.

${ }^{11}$ S. Vrtel-Wierczyński, Wybór tekstów staropolskich. Czasy najdawniejsze do r. 1543, wyd. 4, Warszawa 1969, s. 500. 
szczyźnie z tym wyrazem chleb konkuruje wyraz pieczywo (por. białe pieczywo = chleb biaty). Natomiast pol. ciasto ma więcej znaczeń niż ros. mecmo, gdyż oznacza zarówno substancję, z której przygotowuje się wypiek, jak i sam wypiek.

Przykłady różnych komponentów identycznych subpól i mikropól:

a. w mikropolu „kawał(ek) chleba”: pol. pajda (bajda), skiba - ros. ломоть; pol. kromka — ros. кусок, краюшка; pol. kawat(ek) — ros. кусок, кусочек; pol. przylepka - ros. горбушка;

b. w subpolu „wyroby cukiernicze”: ros. пирожное — pol. ciastko; ros. печенье - pol. herbatniki, ciast(ecz)ka; ros. кулич — pol. babka;

c. w mikropolu „ciastka”: ros. картошка — pol. bajaderka; ros. заварное пирожное — pol. ptyś.

W wypadku tych różnic możliwe są trzy sytuacje: obydwa wyrazy mają słowiańskie pochodzenie (babka - кулич); w jednym języku występuje wyraz rodzimy (słowiański), któremu w drugim języku odpowiada wyraz zapożyczony (бублик — germanizm precel(ek); лепешка — germanizm placek); w obydwu językach występują wyrazy zapożyczone (germanizmy bochenek i бyxaнкa, strudel і штрудель, nawiązująca do niemieckiego Kartoffel картошка, oraz pochodząca z portugalskiego bajaderka).

Do formalnych różnic należą w bliskich według formy odpowiednikach różnice rodzajowe i paradygmatyczne (por. rosyjski nieodmienny rzeczownik безе [rodzaj nijaki] i pol. beza [rodzaj żeński]; ros. буханка [rodzaj żeński] i pol. bоchenek [rodzaj męski]).

Przykład różnej mocy derywacyjnej formalnie identycznych wyrazów stanowią ros. mecmo i pol. ciasto. Wyraz polski ma większą moc derywacyjną (ciastko, ciasteczko, ciastkarnia, ciastowaty), natomiast dla ros. mecmo w języku literackim mamy tylko przymiotnik mестообразныци.

Odnaleźć można również przykłady leksemów zajmujących odmienne miejsca w systemach leksykalnych obydwu języków. Rosyjski блин odpowiada pol. naleśnik. Jednak wyrazy blin, blinek znane są regionalnym odmianom języka polskiego, występują bowiem na Kresach północno-wschodnich i południowo-wschodnich, czyli znajdują się na peryferiach obszaru języka polskiego. Inny przykład: pol. babka odpowiada ros. кулич, jednak w gwarach rosyjskich (np. archangielskich) i w polskich gwarach kresowych południowo-wschodnich w znaczeniu кулич używa się wyrazu paska // pasxa; wyraz ten także znajduje się więc na peryferii geograficznej (w dialektach polskich i rosyjskich). Porównaj definicję paski występującej w gwarach archangielskich: „Паска. Обрядовое выпеченное изделие, изготавливаемое на религиозный праздник Пасху, выпекается, как правило, из муки, творога, изюма"12.

12 И.Г. Ильинская, К проблеме системных отнотений в лексике. Лексико-семантическая группа „Выпеченные изделия” в архангельском диалекте (семантический и лингвогеографический аспекты), Москва 1998, s. 270. 
Należy również zauważyć, że leksem nieistniejący w jednym z porównywanych języków na płaszczyźnie synchronii mógł występować w historii języka. Na przykład rosyjskiej nominacji zboża — рожь — odpowiada polskie żyto. Jednak w staropolszczyźnie znany był leksem reż (Iaco mi Jacub pobral szeszdzesant kop rs z i , a zadwe grziwne lank-Roty Przysiag Sadowych ${ }^{13}$. W języku staropolskim były aż trzy wyrazy określające ten gatunek zboża: reż, żyto i biel (np. w Biblii Szaroszpatackiej czytamy: a pszenycza a byel nyegest zabyta, bo soo biła pozd$\left.n a^{14}\right)$. Spośród tych trzech wyrazów zwyciężyło żyto.

Jeżeli chodzi o podstawę słowotwórczą pochodnych nazw wyrobów piekarniczych, w obydwu językach występują między innymi nazwy odonimiczne (pochodzące od onimów):

a. od toponimów — herbatniki „Kubanki”; ros. Крымская смесь; nazwy gatunków pieczywa — ros. бородинский, рижский; nazwy ciastek — pol. wuzetka (od nazwy trasy WZ 'Wschód - Zachód'); karpatka (od Karpaty); nazwa bułki ros. свердловская булочка; nazwy pierników — ros. вяземские, тульские, pol. pierniki toruńskie;

b. od antroponimów — pol. katarzynki (= pierniki toruńskie); szarlotka (ros. шарлотка); napoleonka (ros. наполеон).

2. Możliwe jest konfrontatywne badanie pewnej części materiału, na przykład frazeologii związanej z chlebem i wyrobami piekarniczymi. Niektóre frazeologizmy i przysłowia zostały przytoczone we wcześniejszej partii tekstu.

3. Możliwe jest podejście etymologiczne. W trakcie tej analizy możemy ustalić między innymi jednakowe pochodzenie ros. баранка i pol. ob(wa)rzanek, wykryć związek etymologiczny między ros. бублик a polskim bąbel(ek) i tym podobne.

Analiza etymologiczna ujawnia odrębną warstwę leksykalną, mianowicie pożyczki z języków obcych, które świadczą o związkach Polaków i Rosjan z innymi narodami. Te wpływy mogły odbywać się poprzez kontakt z obcojęzyczną literaturą albo być wynikiem bezpośrednich kontaktów z językiem-nadawcą. W obydwu językach występują zapożyczenia z niemieckiego (np. ros. крендель, pol. placek/placuszek, precel(ek), pampuchy i naмnyшкu, zresztą sam wyraz chleb jest pochodzenia gockiego), z francuskiego (ros. батон, багет, безе i pol. beza), z włoskiego (tartynka i тартинка, tort i mopm), z łacińskiego (butka od bulla), opłatek (od oblāta). W języku rosyjskim znajdują się również wyrazy ugrofińskie (сайка pochodzi z estońskiego), tureckie (nр. чебуреки, чак-чак) czy kaukaskie (лаваи, хачапури). Tłumaczy się to bezpośrednimi kontaktami Rosjan z tymi narodami. O dziejach stosunków z innymi państwami może świadczyć na przykład taka - wydawałoby się polska - nominacja, jak katarzynki. Niemcy, którzy mieszkali w mieście Thorn (tak do 1919 roku nazywał się Toruń), piekli pierniki

\footnotetext{
13 S. Vrtel-Wierczyński, op. cit., s. 46.

14 Ibidem, s. 79.
} 
na dzień św. Katarzyny. Za sprawą ludności niemieckiej wyrób ten, z nazwą katarzynki, rozpowszechnił się wśród Polaków.

Dużo można by jeszcze napisać o odmiennych podejściach do tematu. Wystarczy wymienić na przykład porównanie nazw różnych gatunków białego pieczywa i razowego. I w Polsce, i w Rosji wiele jest tych nazw, zwłaszcza jeżeli chodzi o piekarnie prywatne (np. nazwy chleba: Kołodziej, Dziadek, Chleb staropolski, Chleb wileński, Chleb góralski, Бородинский, Рижский, Ароматный).

W niniejszym artykule chciałam jedynie zasygnalizować, że nazwy chleba i wyrobów piekarniczych są ważnym przedmiotem badań, a badania te są wieloaspektowe.

\section{Bibliografia}

Arct M., Stownik ilustrowany języka polskiego, t. 2, wyd. 3, Wydawnictwo M. Arct, Warszawa 1929. Bartnicka B. et al., Мы учим польский язык. Начальный курс. 1. Тексты, Warszawa 1999.

Vrtel-Wierczyński S., Wybór tekstów staropolskich. Czasy najdawniejsze do r. 1543, wyd. 4, PWN, Warszawa 1969.

Wysoczański W., Zespalanie pojęć z wyrazem woda we frazeologii oraz w paremiologii polskiej i słowackiej, [w:] ,Вода” " славянской фразеологии и паремиологии. A víza szláv frazeológiában és paremiológiában. Water in Slavonic Phraseology and Paremiology, red. Z. András, O. Fedosov, J. Szabolcs, t. 1, Tinta Könyvkiadó, Budapest 2013.

Пастернак Б., Сочинения в 2-х томах, Тула 1993.

Ильинская И.Г., К проблеме системных отношений в лексике. Лексико-семантическая группа „Выпеченные изделия” в архангельском диалекте (семантический и лингвогеографический аспекты), Диалог МГУ, Москва 1998.

Маринина А., Последний рассвет, ЭКСМО, Москва 2014.

Маяковский В., Стихотворения и поэмы в двух томах, t. 2. Поэмы, Государственное издательство художественной литературы, Москва 1961.

Черных П.Я., Историко-этимологический словарь современного русского языка, t. 1 А. Пантомима, Русский язык, Москва 1994.

Элиасов Л.Е., Словарь русских говоров Забайкалья, Издательство „Наука”, Москва 1980.

\section{On daily bread. The names of the bread and its products in Polish and Russian}

Summary

In this article we analyzed the names of the bread and its products in Polish and Russian. Some aspects of the confrontative investigation are proposed (the lexical and semantical approach, the etymological approach, the phraseological approach and the other aspects).

Keywords: bread, Polish, Russian, phraseology, etymology 


\section{О хлебе насущном. Название хлеба и хлебобулочных изделий в польском и русском языках}

Резюме

В статье проанализированы номинации хлеба и хлебобулочных изделий в польском и русском языках. Предлагается ряд подходов при конфронтативном исследовании данной темы (лексико-семантический, этимологический, фразеологический и другие).

Ключевые слова: хлеб, польский язык, русский язык, фразеология, этимология 